\title{
The Naqli and 'Aqli Integration in the Teachings of Community Health Posting
}

\author{
Dzulkhairi MR, Zairina AR, Nooriah MS, Yunus M \\ Faculty of Medicine and Health Sciences, Universiti Sains Islam Malaysia, Jalan Pandan Utama Pandan Indah, \\ 55100 Kuala Lumpur.
}

\begin{abstract}
The Community Health Posting teaching module is incorporated in the fourth year medical curriculum at Universiti Sains Islam Malaysia (USIM). The integration of Islamic principles and values in the medical curriculum is emphasized during the Community Health Posting. The Community Health curriculum allow students to appreciate and understand the medical and fiqh aspects of health and disease, the social issues in medical practice and research and to inculcate the practice of Islamic professional etiquettes. The teaching module illustrates the relevance of humanities in understanding illness and medical care within the community. Teaching and learning activities include components that enable the students to explore a wide range of influencing factors and how these affect the patients and their families. Issues pertaining to psychosocial and ecological perspectives of the community are also discussed. This posting utilizes various teaching and learning techniques such as lectures, tutorials, seminars, group discussions, educational visits, practical sessions and patient bedside teaching. In addition, the students are equipped with Islamic knowledge through the integration of Naqli and Aqli components in the Community Health Posting curriculum.
\end{abstract}

KEYWORDS: Community Health, Naqli, integration, Islamic input

\section{INTRODUCTION}

The Community Health Posting is conducted over a nine-week period during the fourth year of the Bachelor of Medicine and Surgery (MBBS) programme conducted by the Faculty of Medicine and Health Sciences (FPSK) of USIM. During this posting, the core knowledge of public health, comprising basic concepts of public health, epidemiology, medical statistics, demography, family health, environmental and occupational health, health promotion and nutrition will be reinforced through experiential learning. The uniqueness of the Community Health posting for USIM MBBS programme is that this posting adopts the humanistic approach and it also incorporates Islamic principles and values which are in line with the faculty's mission and vision. The faculty's vision is to uphold the various fields of

Corresponding author:

Dr. Mohd Dzulkhairi Mohd Rani, Faculty of Medicine and Health Sciences, Universiti Sains Islam Malaysia, Jalan Pandan Utama Pandan Indah, 55100 Kuala Lumpur.

Tel: $+603-42892400$

Fax: $+603-42892447$

Email:drdzulkhairi@usim.edu.my medicine and health sciences as prerequisites for meaningful contribution to the society and mankind. Its mission is to strive to become a leading institution that promotes and integrates Islamic values in acquisition of knowledge in the fields of medicine and health sciences and to be at the forefront in solving contemporary issues concerning the society and Islam through utilization of current approaches and technologies.

Omar Hasan Kasule presented a paper entitled 'Concepts of Islamic Medical Education' at a conference organized by the Islamic Medical Association of Malaysia at Kota Bharu, Kelantan in June 1996 where he mentioned about six (6) conceptual issues in Islamic Medical Education. The conceptual issues were the purpose of medicine, integration of the curriculum, the service vocation in medicine, physician leadership role, medical research as ijtihad, and physician motivation. ${ }^{1}$

\section{THE COMMUNITY HEALTH POSTING IN UNIVERSITY SAINS ISLAM MALAYSIA (USIM)}

The Community Health Posting of FPSK USIM is a continuation of Community Health subjects that had being taught to the medical students in Year 3. The practical aspect of Community Health, community based research and intervention programme, district hospital attachment as well as visits to various health 
related institutions are incorporated into the 4th year of the medical training. During this posting, the students are stationed in the health district of Tampin, Negeri Sembilan for attachment. This posting utilizes various teaching and learning techniques such as lectures, tutorials, seminars, group discussions, educational visits, practical sessions and bedside teaching of selected cases of public health importance. At the end of the Community Heath Posting, students are expected to know the functions of District Health Office and Public Health Organization and its functions, analyze community health problems of a selected community and conduct a health survey, organize a health intervention programme and health promotion activities based on the formulated community diagnosis. Through these activities, the students are expected to master the skills of effective communication and taking into consideration Islamic values when dealing with patients and members of the community.

\section{INTEGRATION OF NAQLI AND AQLI COMPONENTS IN THE TEACHING MODULE}

The first revealed verses of the Qur'an state: Recite in the name of your Lord who created. Created man from a clinging substance. Recite, and your Lord is the most Generous. Who taught by the pen. Taught man that which he knew not. ${ }^{2}$ Thus, Islam indeed encourages its followers to seek knowledge, and it is the religious duty of the Muslims to seek and disseminate knowledge. Medical knowledge is important and it is the collective duty of a Muslim physician to teach other Muslims to excel in the field.

The objectives of integrating Naqli (revealed knowledge) and Aqli (by reasoning) and Islamic values in the medical curriculum is emphasized in Community Health Posting. It encompasses the appreciation and understanding of the medical and fiqh issues of health and disease, the social aspects of medical practice and the conduct of research and adherence to Islamic professional etiquettes.

2.1 Exploration of Socio-Cultural and Spiritual Aspects in Patients' Community-Based Case Study

In this module an understanding of the psychosocial aspects of the patient's medical condition is given particular emphasis. Attention is given to several aspects of the patient's illness, attitude, coping strategies, living environment and family behavior. Students are also required to have sound clinical knowledge in order to explain to the patient regarding their ailments. The students are expected to discuss with the patient regarding the disease from the Islamic perspective, whereby the acceptance of the disease is very important. The diseases are tests created by Allah so that Muslims will long for heaven, contemplate their blessings, the gift of health granted to them by Allah and give thanks to Him and also realize how weak they are, which should make them surrender to Allah with all their heart. Muslim patients need to understand that the occurrence of disease as qadar. It is Allah's pre-destination that a person falls sick. However they must understand that prevention and treatment of disease are not against qadar. Medical treatment is subsumed under the principle that qadar can reverse another qadar. Allah had stated in the Quran: And when I am ill, it is He who cures me. ${ }^{3}$

\subsection{Sharing Knowledge In Medical Fiqh Issues And Rukhsah Ibadah}

During hospital attachments and home visits, students are exposed to patients with various types of medical conditions. Some of the patients have acute diseases while others have chronic diseases. Some of the patients with chronic diseases are bed-ridden and unable to look after themselves. This is the opportunity for the students to explore the religious practice of the patients. Diabetic patients on insulin therapy often experience hypoglycaemic attacks during the fasting month because they do not adjust the dose and time of insulin administration properly. Patients with bladder incontinence, on continuous bladder drainage bag or on stoma bag often are in doubt when performing prayers (solat) and they do not know that they must perform it with their conditions. Some of the patients who are immobilized due to injury or medical condition often ignore their religious duty due to not having enough knowledge how to perform their prayers in supine or sitting positions. With proper guidance and discussion of the patient's conditions, the students are provided instruction on rukhsah ibadah so that they can share their knowledge with the patients.

\subsection{Educational Visits to Selected Institutions}

During this posting, students are required to organise educational visits to several institutions. Among the institutions selected include clinic for the elderly in Tampin, old folks home and rehabilitation center for children with special needs.

Visits to clinic for the elderly and old folks home is in line with the teachings of our prophet. Prophet Muhammad (Peace and Blessings be Upon Him), taught the importance of caring for the elderly irrespective of sex, color, or religion, and the Prophet (PBUH) himself set a great example in practicing the principles he taught. In a hadith narrated by Anas ibn Malik (may Allah be pleased with him), the Prophet (Peace and Blessings be Upon Him) said, "If a young man honors an elderly on account of his age, Allah appoints someone to honor him in his old age (At-Tirmidhi)".4 The Prophet also considered respecting the elderly is a way to show reverence for the Almighty. In another hadith, Abu Musa Al-Ash ari (may Allah be pleased with him) narrated that the Prophet (peace and blessings be upon him) said, "It is out of reverence to Allah to respect the white-headed (aged) Muslim (Abu Dawud)". ${ }^{5}$

Besides respecting the elderly, Islam also teaches us to be kind to the children because they are a great blessing from Allah. Visit to special need children 
rehabilitation center enable the student to learn the needs of special children (with physical or mental disabilities), ways to approach them, participation in the rehabilitation activities, interact with their family members, determine their barriers to wellness and plan the best rehabilitation method to optimise their physical and mental functions. The Prophet showed great compassion for children as reported by Anas ibn Malik (may Allah be pleased with him), the servant of the Prophet, had another recollection: I never saw anyone who was more compassionate towards children than Allah's Messenger (peace and blessings be upon him). His son Ibrahim was in the care of a wet nurse in the hills around Madinah. He would go there, and we would go with him, and he would enter the house, pick up his son and kiss him, then come back. ${ }^{6}$

\subsection{Effective Muslim Communication Skills}

Effective communication skill is one of the important skills that medical students need to cultivate. As future doctors, they must be able to communicate well with the patients and their families. As asserted by the Association of American Medical Colleges, "Physicians must be able to communicate with the patients and patients' families about all of their concerns regarding the patients' health and well being". Talking to patients is not solely meant for understanding their thoughts and attitudes; it also serves as an avenue for students to learn about the appropriate professional relationship between patients and students. Students are taught to approach a Muslim patient with salam and smile. Abu Hurairah (may Allah be pleased with him) narrated that the Prophet (peace and blessings be upon him) said, "The young should (initiate) salutation to the old, the passerby should (initiate) salutation to the sitting one, and the small group of persons should (initiate) salutation to the large group of persons" that hadith, the Prophet (peace and blessings be upon him) gives practical examples of Islamic etiquette and starts with a token of respect to the old. Thus the young should take the initiative towards the elders in greeting and also helping, showing kindness, visiting, advising, phoning, and so on. Proper addressing of the elderly with the address Encik, Tuan Haji, Puan or Hajah is encouraged.

\subsection{Community-Based Scientific Research Project and Intervention Programme}

Community-based study is a group scientific research project, which is carried out during the Community Health Posting. By doing the research, the community's health problems are identified, studied, analyzed and discussed. Proper intenvention is planned and implemented based on the study outcome. Dissemination of study results is done by presenting the result of the study at local and international conferences as well as in the medical journals.

Early Muslim scholars used to acquire an extensive knowledge, not only in Islamic and linguistic studies, but also in the fields of medicine, chemistry, and natural sciences. Knowledge has to be based on evidence. 8 In the Holy Quran, Allah says: ...can there be another god besides Allah? Say bring forth your proof if you are telling the truth!.9 Based on the above, scientific research is considered by some scholars as fardhu kifayah (collective religious duty).

\section{THE OUTCOME OF NAQLI AND AQLI INTEGRATION IN COMMUNITY HEALTH POSTING MODULE}

In general, the students have acquired Islamic knowledge through the integration of Naqli and Aqli components with Islamic principles and values in the Community Health Posting. These were demonstrated by the use of certain selected hadiths and Quranic verses in the case presentations, essays and case write-up of the students. During the presentation of community-based case study, the medical students discussed their study findings including the Islamic perspectives.

\section{DISCUSSION}

Integration of Islamic input in the medical curriculum of USIM is unique.10 The components of Naqli and Aqli with Islamic principles and values had been succesfully integrated into the Community Health Posting curriculum since the beginning of the programme. The Islamic input in medical education provides both professionalism, with divine injunctions of perfection and competence, together with a holistic approach towards patients, family, society, disease, health, life and death.11 The integration of Islamic principles and values in the medical curriculum represents a new paradigm shift in medical education that aims to inculcate ethical values in the students so that upon graduation, they will be a different 'breed' of doctors who not only excel in performing their professional duties but also portray conduct (akhlaq) expected of a good Muslim.12 Effective communication skills are also important in becoming a good Muslim doctor. Students are taught during this posting on making the five axial diagnosis which consist of physical, psychological, social and behavioural diagnosis as well as effect on functioning of patients.13 At the end of the posting, the students are able to describe the importance of comprehensive and holistic care in patient management.14 By conducting communitybased research, students familiarize themselves with common medical problems and health issues faced by the community. Throughout the planning and implementation period the medical students work closely with the district health officer and staff and with the village committee. They also have to recognize the role of political figures in the district. In short, their research activity will lead them to recognise the key members in the community involved in health activities and how they can be mobilized. As with other universities, the major constraints of the Community Health Posting are time and funding. 15 The time given ( 4 weeks) to conduct the study is often inadequate for comprehensive data collection. The 
constraint due to limited funds can hinder students from exploiting various strategies in the intervention activities.

\section{CONCLUSION}

In general, the students have acquired Islamic knowledge through the integration of Naqli and Aqli components in the Community Health Posting. This had been demonstrated and reflected by their ability to use quotation from the Quranic verses, ability to use hadith and relate with the discussion of their patients condition, conduct health intervention programme based on scientific research and practice effective communication skills which is in line with Islamic teachings.

\section{REFERENCES}

1. Omar HK. Concepts of Islamic Medical education. Paper presentation at 4th Annual General Meeting of The Islamic Medical Association Malaysia.

Kubang Kerian, Kelantan 7th June 1996. Available from: http://omarkasule.tripod.com.

2. The Holy Quran. 96:1-5, Sahih International. Available from http://quran.com/96.

3. The Holy Quran. 26:80, Sahih International. Available from http://quran.com/26/80.

4. Imam Al-Nawawi. Riyad-us-Saliheen, Book 1. Dar-us-Salam Publications. 1999.

5. Imam Al-Nawawi. Riyad-us-Saliheen, Book 1. Dar-us-Salam Publications. 1999.

6. Imam Muslim. English Translation of Sahih Muslim. Kitab Bhavan, India. 2000.

7. Muhammad Ibn Ismail Bukhari, Muhammad Muhsin Khan. The English Translation of Sahih AlBukhari. Al-Saadawi Publications. 1996.

8. Fadel HE. Ethics of clinical research. An Islamic Perspective. Journal df Islamic Medical Association Of North America 2010; 42: 59.

9. The Holy Quran. 27:64, Sahih International. Available from http://quran.com/27/64.

10. Jamilah J, Ahmad Najib A, Dzulkhairi MR, Ariff HO, Nasri Ismail NM. Integration of Islamic Input in Medical Curriculum - Universiti Sains Islam Malaysia (USIM) Experience. The International Medical Journal Malaysia 2014; 13:73-77.

11. Tayyab H, Hamdan N. Inculcating Islamic Input in the Curricula of Medical Sciences at Pre-clinical years (basic medical sciences). Fima Yearbook 2009: 29-45.

12. Osman A. Islamic Input in Medical Program at IIUM: The way forward. International Medical Journal Malaysia 2010; 9:3-4.

13. Sherina MS. The Community Follow-Up Project: An Approach to Comprehensive Patient Care. UPM Publications 2005.

14. Sherina MS, Azhar MZ, Abdullah MY. After The Hospital Episode - The Community Follow-Up Project. Asia Pacific Family Medicine 2004; 3:1-8.

15. Haliza MR, Abdullah MY. More than patient care: The community medicine attachment and community follow-up models. Brunei Darussalam Journal of Health 2006; 1:69-76. 